\title{
The Productivity of Political Imprisonment: Stories from Rhodesia
}

\author{
Jocelyn Alexander
}

University of Oxford

\begin{abstract}
Political prisons are not only places of violence and silence. They are also productive. Building on recent literature that pays close attention to prisoners' social and political projects, the article argues that significant, often hidden, aspects of political work take place within the prison, and reach beyond its walls. A focus on the writings and oral histories of political prisoners reveals a remarkable range of imagination and practice within the tight embrace of a hostile state, and shows also its post-colonial reverberations. Through a focus on settler-ruled Rhodesia, I explore the projects and possibilities of nationalists in detention and guerrillas in maximum security prisons, noting their varied and shifting modes of story telling, and the political charge of these stories in the present.
\end{abstract}

Keywords: political prisoners, colonial prisons, Rhodesia, oral history, letters

\section{Introduction}

Recent studies of colonial incarceration have turned our attention from its strictly repressive functions to its frequent failures to silence, subjugate or 'rehabilitate' political actors. Drawing on diverse sources, this literature has outlined a productive politics of the prison that pays close attention to political prisoners' social identities and projects. ${ }^{1}$ To choose to focus on these themes is not to underplay the violence and silences of prison but rather to emphasise that the colonial prison was not only a space of terror inhabited by the 'socially dead'. ${ }^{2}$ These institutions were rarely 'panoptic' in design, and rarely intended -or able -to achieve the 'isolation and surveillance of the individual': they were more often violent, 'porous' and communal. ${ }^{3}$ Within these contexts, political prisoners' varied interlocutors and audiences included peers and political constituencies as well as lawyers, officials, religious communities, human rights groups, and kin, all of whom shaped prisoners' strategies within prison as well as their engagement in worlds beyond the prison walls, even beyond the nation.

These connections are the stuff of sociality - bonds, expectations, and obligations - not isolation. My concern with them here is to explore what they can tell us about the varied politics made in colonial prisons and their post-colonial afterlives. The prison is a productive space of a particular kind. It is closely framed by a hostile state and requires constant choices regarding relations with authorities and the making and maintenance of the boundaries and substance of political community. Within these tight confines the work of education, broadly defined, and self-making take on weighty political connotations. The strictures of prison also produce an explicit, and hence revealing, kind of claim-making on those outside, usually through intermediaries or letters, and often burdened with both existential weight in the present and fragile aspirations for the future. The memories of these experiences of political imagination and practice acquire significance in post-colonial contexts as they are narrated in private and public. They may inscribe a nation or legitimize claims to power. They may as easily describe exclusion, unrecognized sacrifice, and 
the failure of political futures imagined in prison, their absence a potent reminder of a foundational politics gone awry. Such processes were not generic, and their differences are revealing. They are also always unfinished - prison produces a recidivist memory that is revisited for new purposes over time.

To ask what kinds of politics are made and unmade in and by prisons is not a question that is easily broached, crossing as it does a host of evidentiary, chronological, and geographic boundaries. In the shadowy spaces of carceral institutions, evidence is only unevenly available, implicated in past and present political regimes, and resistant to singular interpretation. I start with a discussion of these challenges before turning to the case of settler-ruled Rhodesia and its political prisoners.

\section{Archives, texts and stories in the political prison}

Sources related to the political prison are usually partial and full of holes. Evidence may be produced, suppressed or distorted in attempts to protect the reputations of states or the heroism of nationalists, or for a host of other reasons. Political prisoners' accounts are seldom heard. In prison they might be censored, or muffled by isolation. A lack of education or the wherewithal to write might also prove insurmountable obstacles to communication with a public. Story telling tends to favour the voices of the educated and the eventually victorious. For their part, state archives have often been purposely destroyed or accidentally neglected, and some state institutions laid only the thinnest of documentary trails. Even where archives are substantial and accessible they are always already winnowed.

It is nonetheless possible to reconstruct a great deal from the traces of political imprisonment. Even when state archives have lain hidden they sometimes re-emerge, as famously in the case of the archives that British officials 'migrated' at the moment of decolonization, and which held damning material on Kenya's Mau Mau detainees, among others. ${ }^{4}$ Even where archives are thin or have been thinned, they express particular state cultures and sensibilities. ${ }^{5}$ They may tell us about what officials wanted to know - what they considered relevant to their own governmental aims and what they did not or could not know. They may reveal official interpretations and representations of political threats and their remedies. In some bureaucratic states, records contain a wealth of detail on mundane, daily practice. In others, such records can be fleshed out by searching out the residues of debate among state institutions, and between them and the colonial state's critical interlocutors such as prisoners' lawyers and solidarity organisations, each often holders of their own archives.

John McCracken's study of Nyasaland's late colonial practices of detention demonstrates the considerable utility of these kinds of records. Drawing on a combination of official archives and the files kept by detainees' lawyers and support groups, McCracken was able to trace the institutional and ideological influences of Kenya's experience of Mau Mau and Colonial Office views on the Nyasaland government's response to Hastings Banda's Malawi Congress Party. ${ }^{6}$ At first, policy tended to violent repression and an attempt to cast Congress as both irrational and curable in the mould of the 'diagnosis' of Mau Mau adherents, and therefore in need of a Kenya-style detention 'pipeline'. This view suffered a near total reversal following interventions by the Colonial Office. In the end, 'All references to rehabilitation and confession had been dropped as had any indication that detainees ... were psychologically disturbed'. Over the course of just one year, McCracken 
shows, Congress was redefined as a party with 'legitimate political views' and the move to independence - with former detainees at its helm - was set in train. ${ }^{7}$

Such sources are indispensable for tracing international exchanges of ideas and the local specificities, knowledge production and lobbying that, in practice, greatly shaped interventions and political readings, and which ultimately played an influential role in determining who the beneficiaries of independence would be. State archives and related documentary collections are thus essential to constructing certain kinds of history. However, even read 'against the grain', they direct our attention to institutions, officials and elites. ${ }^{8}$ They are less good at unravelling the meanings and uses made of prison by political prisoners themselves, that is the 'productivity' of prison in the making of social and political relations, hierarchies, claims and ideas. To gain access to this vantage point, I focus on the uses of political prisoner memoirs, letters and oral history.

Memoirs are not always numerous or representative of political prisoners, but they offer unique views and, where a density of memoirs has been produced such as in South Africa and Kenya, they have been effectively used for a variety of purposes. They have served, for example, as empirical records of abuses, resistance and experience that are absent from the state's archive. They have also been read as a means by which prisoners reclaimed their selves from the objectifying and subjectifying effects of 'state writing' produced in the course of trials, interrogations and forced confessions. ${ }^{9}$ A key role played by memoir lies in the construction of narratives that play political functions in the present. They may serve as 'cause' writing during the struggle or as means of redemption and nation-building afterwards. They have equally offered jarringly dissonant accounts of both prison and the nation, recording stories of division, neglect, and betrayal. ${ }^{10}$ In this vein, they are essential to explorations of terrains of discord among prisoners and the making - and maintenance - of contested social and political identities. ${ }^{11}$ Prison memoirs have thus been put to use as evidence of repression, as means of 'writing back', and as artful tools of self-representation and narrative, attuned to a shifting politics of the present. In all these guises, they offer a window on the shifting productivity of political imprisonment for both individuals and political communities.

In contrast to the memoir, letters written from prison tend to be more deeply steeped in the demands of day-to-day life and to serve as both public, political appeals and as a private mode of communication. In some cases they provide records of intimate dialogues that can be traced as they evolved over time. ${ }^{12}$ Where they are written under severe constraint, they may focus on the banal or the material, revealing the fine-grained stuff of survival. Because of the stark separations made by imprisonment, however, letters very often acted as a crucial means to 'get traction' and thus make claims and elicit action: in this, they are central to efforts to render prison productive. ${ }^{13}$ They reveal, at times in painful detail, prisoners' efforts to retain valued social roles through demands, admonition, and iterations of obligation. They reveal the tremendous energies that went into imagining futures from within prison, 'futures' that often lived on into post-colonial worlds, but as often created a record that jarred with them. ${ }^{14}$

Though they occupy some of the same terrain, oral histories allow different stories to be told than do these written sources. They allow people who were neither literate nor leaders (nor victorious) to tell tales. This does not produce some greater truthfulness: like political prisoners' texts, their oral histories reflect their 'social worlds' and the kinds of stories authorized within them. ${ }^{15}$ Even 'counter-narratives' respond to a dominant story or culture, though their effect or intent may be to 
undermine or subvert it. Such kinds of stories are not static in themselves or in relation to a public sphere: they may rest unacknowledged but 'festering', and they may burst into the open when political shifts open up the possibility of different ways of talking about the past. In this they are a powerful resource that animates an always unfinished politics of belonging and exclusion and ongoing efforts at claim-making and legitimation. ${ }^{16}$

Prisoners' 'buried' stories have offered revealing views of post-colonial politics. We might think of the stories prison gang members in South African prisons told in order to claim political belonging, and the terrible exclusionary effects of the transitional regime's refusal to accept them as deserving of the franchise or amnesty. ${ }^{17}$ In Mozambique, Harry West has argued that the FRELIMO activists imprisoned by the Portuguese secret police in the 1960s and 1970s were not accepted as part of FRELIMO's revolution after independence. Instead, they were judged to be dangerously unreliable - even unknowable - owing to their extended proximity to the Portuguese state and the effects of torture on their capacity for loyalty. Despite their terrible stories of suffering in prison, they were placed alongside groups designated as suspect by FRELIMO, the 'compromised' and the 'unproductive'. ${ }^{18}$ The stories that these former prisoners told were not however expunged by their fraught relationship to dominant political discourses. Even where such accounts are spoken of as 'silenced' by former prisoners, as in Mozambique, they are rarely completely so: the circulation of stories about silenced stories is a kind of narrative strategy too, and it sustains political identities. Over many years, these oral accounts may continue to circulate, privately and semi-publicly, and to carry a great weight of loss and suffering along with a latent political charge that is crucial to understanding the complex legacies of the political prison.

Drawing on this range of sources, I turn to an exploration of the productivity of political imprisonment in Rhodesia. I construct a series of incomplete vignettes based on oral and written sources produced by prisoners at different moments. They recount and record particular political and military histories and their engagement with distinct prison regimes, and they underscore the varied ways in which ideas about political community and social relations, once formed in prison, invaded the present.

\section{The Rhodesian Way of Prison}

As in other cases, the sources on which I draw to explore the productivity of prison in Rhodesia are shaped by both the nature of the prison regime and the contexts in which stories about this history have been written and told. The record keeping practices of the Southern Rhodesian state and its interlocutors were impressively dense but shifted over time and space, while the stories told by its political prisoners were moulded by both their individual experience of prison and the value placed on that experience by an official nationalism in independent Zimbabwe.

Large-scale political imprisonment was initiated in Southern Rhodesia in 1959, hand in hand with a state of emergency that spread across the whole of the Central African Federation (Southern Rhodesia along with its neighbours Northern Rhodesia and Nyasaland, today's Zambia and Malawi). As in many colonial contexts, the rise of a nationalist challenge was met with state repression and specifically detention, but in Rhodesia it took an unusual form. Instead of condemning nationalists as criminals and terrorists, or indeed as mentally ill, and prescribing regimes of punishment and rehabilitation to suit, the Southern Rhodesian government at first 
accorded its detainees a limited set of rights that distinguished them from criminals and obliged the state to compensate them materially for their loss of freedom. Officials rarely used the word 'rehabilitation', and when they did it referred to the physical conditions and welfare needs of detainees and their families. ${ }^{19}$

This regime caused great hardship - in terms of the loss of liberty and access to the protections of law, as well as broken relationships, crushed aspirations and failed livelihoods. Even so, the stark contrast to the violence and scale of detention in the contemporaneous settler state of Kenya is stunning. Southern Rhodesia's early policies were the product of the multi-racial politics and promise (but not delivery) of rights to educated, middle-class Africans of the 1950s, the hallmark of the Central African Federation. They reflected this regime's political investment in law and expert bureaucracy as forms of authority, an investment rooted in a longer history that had produced Rhodesia's centralised, rule-bound state, and which contrasted with the decentralized coercion (legal and illegal) of Kenyan institutions and settlers. ${ }^{20}$ This approach to detention established a literate and legalistic mode of interaction with political prisoners that never fully went away and that can be traced - precisely because it is literate and legalistic - in the archives of the state, law firms and solidarity groups. ${ }^{21}$ These exchanges took place alongside a legion of courtroom challenges to detention, which nationalists used to underscore their commitment to the rule of law as an ideal, and to draw attention to what they saw as its degradation under emergency legislation. In this, their educated and legally knowledgeable status loomed large as a component of their claim to authority and citizenship. ${ }^{22}$ The picture that emerges from these sources is essential to comprehending the kinds of selfgovernment nationalists attempted in prison, the stories they told about it, and postcolonial invocations of this history.

The rise of the Rhodesian Front marked the progressive demise of the efficacy if not necessarily the appeal of these modes of contestation. For the Rhodesian Front, nationalists were not citizens with rights but thugs, criminals and terrorists who had rejected its much narrowed offer of citizenship. The Front relied ever more heavily on coercion and a populist white nationalism which recast law as an expedient tool, not a source of rights. Detention was remade in the process: it became a means of exclusion, literally placing detainees at the remotest edges of 'the bush', that catch-all signifier of the uncivilised. This did not, however, lead to the development of any rehabilitative project. Rehabilitation for the Rhodesian Front entailed sending a handful of men, led by a former Native Commissioner, to try to convince detainees to switch sides, an effort that was rapidly abandoned in the face of implacable hostility. ${ }^{23}$ Unlike its counterparts in Kenya, the Rhodesian Front concluded that the nationalists of ZAPU and ZANU could not be made to join its nation. ${ }^{24}$ The escalation of war became the prime mode of engagement on both sides. The state's archival record grows scant in this later period and prisoners lost much of the leeway they once had to receive visitors, correspond and otherwise address an exterior world. A vast expansion in imprisonment on charges related to the war under a rapidly growing set of emergency and martial laws kept many of the government's opponents - imagined and real - beyond the reach of lawyers and support groups. Who was imprisoned, how, and with what productive potentials was rendered far less readable. $^{25}$

Where documentary evidence thins out, memoir and oral histories become more important to exploring the productivity of the political prison. Zimbabwe has few prison memoirs proper. ${ }^{26}$ In contrast for example to South Africa and India, the prison memoir is not an influential cause-making or nation-building genre and 
nationalist leaders have rarely used prison stories to bolster claims to power. ${ }^{27}$ The dominant story of nationalist heroism established in the 1980s and enacted in the public sphere by Zimbabwe's ruling party, ZANU(PF), is about the gun-wielding men of its guerrilla army and nationalist leaders in exile. Military men have at times denigrated time served in prison as a comfortable or even cowardly form of struggle. ${ }^{28}$ Although many of ZANU(PF)'s most senior leaders spent a decade in prison, along with their counterparts in ZAPU, most made their way into exile in the mid-1970s, when they were released from prison as part of a series of political negotiations. It was in exile that they built their political power. Members of ZAPU who were imprisoned by the Rhodesian Front in the 1960s and 1970s were doubly excluded from Zimbabwe's heroic nationalist mythology - once as prisoners, along with their ZANU peers, and then again as the losers of the first elections of the independence era in 1980. ZAPU's electoral defeat was followed by a period of violent state repression in which over 10,000 were killed and many more were detained, tortured and disappeared. A new generation of political prisoners was created, dominated by members and leaders of ZAPU and its armed wing. In 1987, ZAPU was subsumed into ZANU(PF) under a political agreement known as the Unity Accord, and ceased to exist, creating peace but only a superficial political quiescence. $^{29}$

Political prisoners have sought to contest their exclusion from dominant nationalist narratives in a number of ways. They have constituted informal 'narrative communities', made up of people who have tried to make sense of and give meaning to their shared experiences through 'the use of memory as a rhetorical tool in conversations'. ${ }^{30}$ From the late 1990s, when veterans of the guerrilla armies sought and received compensation and other perks from an embattled ZANU(PF), political prisoners too sought to make claims for their contribution to the struggle, with only very mixed results. As Munyaradzi Munochiveyi has argued, a sense of suffering and sacrifice without recognition has remained potent among settler-era political prisoners. ${ }^{31}$ ZAPU's former prisoners have carved out a distinct space within this wider field. They have often retained their identification with their original party, and a set of ideals associated with it, created in part in prison. This 'buried' history, bubbling under the surface, did not constitute a single narrative, however: it too was subject to contrasts in prison experience and distinctions in post-independence political positioning and alliance.

These varied sources are the products of different kinds of prison regimes and prisoner politics. Prisoner stories are always in some sense tales of communities fractured - by violence, difference, distance - but they also offer a window on how these divisions may (or may not) be remedied in the hard work of making politics in prison and remembering it after.

\section{Productive Prisons: Three Cases}

I take three distinct instances to explore briefly the ways in which these sources may be deployed to explore the productivity of the political prison. I begin with the longest-lived and largest of Rhodesia's early venues of nationalist detention, Gonakudzingwa, before turning to the letters of one man, Maurice Nyagumbo, Rhodesia's political prisoner par excellence, and finally a largely oral-history based exploration of the lives of Zimbabwean and South African guerrillas held in the maximum security confines of Khami prison. 


\section{Nationalist self-government in Gonakudzingwa}

The ways in which nationalist detainees of the 1960s organized their lives in confinement revealed both the aspirations of 1950s' nationalism and the disillusion of the 1960s. By some way the least closely regulated type of political imprisonment, detention offered space not only to imagine political futures but to put ideas into practice. These experiences are recorded in a handful of memoirs written by leaders, but they come through most powerfully in oral histories of party members. Both ZAPU and ZANU experienced detention, but I focus here on Gonakudzingwa, which was the pre-eminent site of detention and which housed the most senior of ZAPU's nationalists, then the dominant nationalist party, along with a fluctuating population of hundreds and at times thousands of ZAPU functionaries and members, many detained for a decade from $1964 .{ }^{32}$ Gonakudzingwa is the very definition of a remote, rural outpost. Located on the southeastern border with Mozambique, detainees shared their homes with elephants and lions while officials only lightly regulated their daily lives. This allowed detainees to develop self-government. In their oral accounts, the nationalists of Gonakudzingwa described in detail how they rejected the authority of state officials, or coopted them, and developed their own institutions, modeled on the party's 'structures', and marked by strict hierarchies, divisions of labour and rigourously time-tabled activities, all noted in meticulous practices of recordkeeping. ${ }^{33}$ ZAPU President Joshua Nkomo's huts were dubbed 'State House' and detainees briefly produced a newspaper, the Gonakudzingwa News. Everyone agreed that the ambition was to make a 'government'. ${ }^{34}$

Detainees' efforts reflected an ideal of the state as rule-bound and expert and they celebrated respectability and education as markers of citizenship. It is not surprising that the most prominent activity organized by detainees was education, ranging from classes for the illiterate taught by detained teachers and university students to advanced degrees by correspondence, the latter with the aid of organisations such as Christian Care. ${ }^{35}$ As in the 'University' of Robben Island, detention became a place where particular aspirations and subjectivities were made and reinforced: they looked to the future nation, to the making of citizens and leaders. ${ }^{36}$ These efforts were also aimed at keeping the peace through the inculcation of restraint and common cause. In their stories, detainees emphasised the uses of song and history-telling as means of developing a shared culture that cut cross ethnic and class diversity. As Welshman Mabhena explained, 'you had to know each other's culture. They'd target the grey-haired ones to teach the young. ${ }^{37}$ Detainees promoted sport, but frowned on the professional foul. Civility and unity was prized above all: detainees even recalled banning 'insulting language'. ${ }^{38}$ Formal courts were created to resolve disputes, and some kinds of accusation were banned as unmanageably divisive and unverifiable - above all, the charge of 'selling out'. ${ }^{39}$

These efforts were fondly, often humourously, recounted in oral histories. They were also considered deadly serious bulwarks against an always present possibility of division and violence, explained as a product of the pervasive boredom, loneliness, depression and anguished worries over distant loved ones, that might find expression in spats and fights, as well as in grander tensions along ethnic and generational lines. The terrible condition of detention itself required this productive outpouring, but it was not always enough. In detainees' tales of the worst outbreak of violence at Gonakudzingwa they held that it was only the agents of the Rhodesian state that were able to quell the violence. These narratives located the cause of the conflagration differently, some stressing the effects on ethnic tensions of rumours of political divisions in exile, others the disrespect of youth for the elderly, still others 
the stirrings of government infiltration, but all located the uncontrollable nature of this violence in the limits of detainee institution-building and the nation-wrecking dangers of unmediated difference. ${ }^{40}$

The valence given these stories shifted over time. For Joshua Nkomo, who wrote his memoir in exile in the early 1980s, having fled in the midst of the worst state violence of that time, the limits of Gonakudzingwa's ability to make government was told as a harbinger of ZANU(PF)'s failed state-building and violently exclusive nationalism of that moment. This is not a nation-making memoir, but a warning. ${ }^{41}$ Nkomo's view echoed widely in ZAPU's strongholds in the 1980s, forming part of a powerful counter-narrative to ZANU(PF)'s depiction of ZAPU as a traitorous threat to the nation. After the signing of the Unity Accord brought Nkomo and other senior ZAPU politicians into government as part of ZANU(PF), however, it became an awkward tale for the party's leaders to tell, thereby creating a rift between them and their erstwhile followers. ${ }^{42}$

In the dramatically changed political context of the 2000s, when I interviewed the former detainees of Gonakudzingwa amidst what was already a prolonged political and economic 'crisis', the act of remembering produced new emphases, notably for those one-time members of ZAPU who had left ZANU(PF) for the newly formed opposition, the Movement for Democratic Change (MDC). ${ }^{43}$ Paul Themba Nyathi looked back on the huge efforts put into constructing rule-bound institutions in Rhodesian detention and judged them 'naïve'. For him, as for his colleague Fletcher Dulini Ncube, both of whom had experienced imprisonment after 2000 as MDC members, another point loomed large. Alongside revisiting the idealistic aspirations of their young selves, they noted with approval the orderliness and capacity of the Rhodesian state as jailer, in marked contrast to ZANU(PF)'s inability to maintain even the barest functioning of prison infrastructure in the 2000s, just one arena in which the bureaucratic state had begun to spectacularly fail its citizens. ${ }^{44}$ This was no nostalgic embrace of settler rule, but something more specific: it underlined the necessity of institutional competence, as against its violent, arbitrary, inept other, as a baseline for legitimate rule, an idea rooted in the political imaginaries born of the 1950s and practiced in the remote outpost of Gonakudzingwa.

\section{Letters and life outside the prison walls}

The stories the former detainees of Gonakudzingwa told in the 2000s about their attempts to govern themselves identified political possibilities foreclosed, but kept alive in memory and circulated in conversation, available for new moments of political challenge. Different stories can be traced in letters. As I have suggested, letters tell us about, and act as an essential tool of, attempts to reach beyond carceral spaces in aid of both personal and political goals. In doing so, they both represent the world and engage with it. In Rhodesia as elsewhere, the capacity to maintain links to the outside world through the letter was constrained by shifting carceral regimes and by the resources and education of individual prisoners. ${ }^{45}$ At some moments, levels of surveillance and repression made it all but impossible to sustain outward connections, notably as the war escalated. But the vagaries of regular political negotiations, the dense range of support networks, pliable warders and high levels of literacy among especially nationalist leaders meant connections were rarely lost entirely.

Prisoners' letters often addressed issues concerning education, abuses and legal battles, ${ }^{46}$ but my focus here is on the construction of efficacious personas able to create obligations and inspire action, and to imagine a future nation - and even to influence its making - from within prison. To illustrate these uses of letter writing, I focus on one of Rhodesia's longest serving political prisoners, Maurice Nyagumbo, 
who was a part of ZANU's cohort of senior detainees. He produced a trove of letters, preserved by the historian Terence Ranger, who was one of his prime interlocutors, owing to the close bonds forged among Nyagumbo, Terence and his wife Shelagh in the early years of detention when the Rangers were centrally involved in the support of detainees. ${ }^{47}$ Nyagumbo also - unusually - wrote a diary in jail (rather than a memoir produced after the fact). ${ }^{48}$ Nyagumbo's capacity to write was disrupted by shifting prison regimes as well as the frequent punishments he suffered for his constant, often violent, challenges to prison authority. The dialogues he maintained by letter were punctuated by long periods of state-made silence. The extent to which Nyagumbo nonetheless maintained a correspondence, via official routes and through smuggling by black warders and fellow prisoners, and intervened in the world, is striking.

Nyagumbo used letters to maintain and indeed construct his most valued social roles - as father, brother and husband - through the post. Over two decades, he used letters to call on friends, kin and others to act on his behalf, and to cajole and chastise family members. In so doing, he invented with written words a self - an absent, patriarchal figure - who deployed the languages of morality, religion, and invented traditions to create obligations, shape behaviour and make community outside the prison and indeed half way around the globe, in England, where several members of his family landed in exile in the war years. Nyagumbo's letters record moments of personal despair, notably when he had news of the struggle faltering, the death of loved ones and comrades, or when his children judged him a 'bad father' or he judged himself a failed husband. ${ }^{49}$ He wrote to Shelagh Ranger in 1978, following the killing by security forces of his close friend Basil Nyabadza: 'my nerve system is completely wrecked. I have no doubt this should disappoint you as it appears as if I can no longer continue with endurance. ${ }^{50}$ But he did continue, leaping back into letter writing to remonstrate with relatives over an interrupted education or an unforeseen pregnancy. ${ }^{51}$ His efforts were at times rewarded, not least by the orchestration of a white wedding for his daughter Chipo by a host of his kin and political and church contacts in England, a result of a great epistolary effort that involved years of remonstrations over her education, marital status and motherhood. His old friend, Terence Ranger, acted as pater familias. Ranger wrote that he 'stood in for you to give Chipo away; we drove to church in a gleaming Rolls-Royce and proudly processed up the aisle.' Terence and Nyagumbo exchanged letters celebrating the event with its niceties of cake and strawberries and talk of Wimbledon at the very height of the guerrilla war. ${ }^{52}$

Another key audience, though one harder to reach, was constituted by Nyagumbo's ZANU colleagues in exile, to whom he addressed political instruction. Many of his closest allies, with whom he had intermittently shared incarceration for years, Robert Mugabe among them, had been released as part of the détente exercise in 1974, and had made their way to Mozambique where they took up political roles at the forefront of the armed struggle. Nyagumbo had also been released but had not wanted to leave the country and was almost immediately re-imprisoned on charges of recruiting guerrillas, a capital offence. ${ }^{53}$ Nyagumbo smuggled out several messages and letters via his fellow prisoner John Conradie. He sought to deliver two messages to ZANU's Central Committee in Maputo, both shaped by his prison life and both appealing to men he had long shared cells with. His first was to tell them to avoid compromises with 'the devil', and on no account to make a deal with ZANU's fellow nationalists in ZAPU, a view shaped in part by his reading of ZANU's growing support from interactions with fellow prisoners and in part from a prison career spent 
denouncing negotiation with officials and alliances with other political movements. For him, compromise constituted nothing less than selling out the revolution. ${ }^{54}$ His harsh views in this regard were in keeping with many of his peers in Mozambique, prefiguring the violent breakdown of cooperation between the two nationalist movements during the transition to independence.

Alongside this uncompromising position sat another that was more in keeping with the figure of the absent patriarch, developed in prison, who had for some decades chastised his family as a moralizing member of the respectable classes. In a letter written in June 1979, and smuggled out of prison subsequently, he addressed his peers at the head of the armed struggle with great passion. Drawing on stories he collected from fellow prisoners recently arrived from the war zones, he sought to alert them to the troubling abuses of ZANU's own guerrillas. He passionately called for tolerance and respect on the part of guerrillas for what he saw as the social mores of rural society. These mores were rooted in what he described as 'well constituted married life, peace, justice, law \& order, personal discipline \& prosperity'. The 'masses' had 'a potentially inexhaustible sense of fairplay', but they - and so too the revolution were threatened by what he depicted as the excesses of the young men with guns, who 'took liberties with women', held 'beer drinking orgies' and used 'terror and torture' against innocent civilians. ${ }^{55}$

Nyagumbo combined a great range of private and public concerns in his letter writing, from white weddings to guerrilla terror, drawing on what he learned, and who he had become, in prison. Though different in tone and tack, his letters were intent on the production of a society and a nation of which he could imagine himself a part, a place that was utterly intolerant of compromise and alternative loyalties to ZANU, but which yearned for and celebrated a social order rooted in the values of a respectable middle class. There are parallels to Nyagumbo's correspondence in prisoner letter writing elsewhere, but there are also differences in the concerns, language and interlocutors. ${ }^{56}$ Letters reveal the production and pursuit of distinct social struggles and political goals within a broader search for means of making life from inside prison. The extent to which Nyagumbo as prisoner shaped himself and the world is a testament to his tenacity and his capacity for making far-flung connections. His letters offer, like the self-governing efforts of Gonakudzingwa, a window on hidden arenas of struggle and their at times surprising, at times prophetic, content.

\section{Soldiers in prison: defending martial minds and bodies}

Let me now turn from nationalist prisoners to a different category, constituted by militarily trained men, convicted under the notorious Law and Order Maintenance Act, and held in maximum security institutions. Guerillas held in these prisons had neither the same opportunities nor the same identities and agendas as the detainees of Gonakudzingwa, or nationalists such as Nyagumbo who moved between the categories of detainee and convict. In comparison to their nationalist counterparts, guerrillas wrote little and were incarcerated in places where state records are particularly scant. Oral history is thus the central means of telling these stories. Here, I focus on the accounts of a number of the survivors of the Wankie and Sipolilo campaigns launched jointly by the South African ANC and ZAPU in 1967 and 1968. These campaigns were military failures: many of their protagonists were killed or captured, ending up in prisons in Rhodesia, Botswana and South Africa, while the fallout of the campaigns produced paralyzing divisions in both movements. Much of what has been written about these events has taken the ANC point of view, and has focused on military tales and political repercussions in exile. ${ }^{57} \mathrm{My}$ focus here is on the Rhodesian prison experiences of a mix of ANC and ZAPU soldiers. I draw on 
interviews with five former soldiers, one ANC and the rest ZAPU, undertaken largely between 2008 and 2010, and the accounts of two further ANC men, one a memoir published in 2005 and the other a transcript of an interview undertaken just after his release from prison in June $1980 .^{58}$

Once captured, most of these men underwent a period of brutal interrogation at the hands of Rhodesian and South African Special Branch officers, after which they were tried and almost always sentenced to death. Most spent several years on death row at Salisbury Central Prison not knowing, day to day, if they would live or die, before their sentences were commuted to life. Most were then transferred to Khami Prison outside Bulawayo where they would spend the next decade, until their release into a majority-ruled Zimbabwe in 1980. Their narratives of these events emphasise a military identity throughout. Up to the point of their imprisonment, the stories of ZAPU's guerrillas echoed those of their military peers outside prison: they recounted journeys and border crossings, the adoption of the identity of the 'professional soldier', rooted in their training, and their bravery and ingenuity in the face of the enemy. ${ }^{59}$ But prison arrested the flow of the soldiers' narrative just as it drastically curtailed their agency. The accounts of confinement begin dramatically, with stories of soldiers' efforts to withstand interrogation, of their rejection of the court's authority as men who were at war with the Rhodesian state, and of living with the sentence of death. ${ }^{60}$ In these dramatic early passages, the immediate effects of arrest and confinement are symbolized by the loss of the gun. Thula Bopela wrote that, as a soldier, he had accepted that he might die 'at any moment': 'In battle, though, one is armed and able to shoot and kill.... In Death Row, however, there are no AK47s and SKS rifles to defend oneself. There is nothing to strike back with but one's spirit. ${ }^{, 61}$ Batandi Mpofu explained, 'Sometimes when you are in the bush, you are better off than someone in prison.... Carrying a gun, you are in control of almost a hundred metre radius, and if anything comes across you can defend yourself, but not when you are in Khami, not when you are in Khami. ${ }^{62}$ Contending with this loss of the soldier's ability to shoot back and command territory marked the stories of life in Khami, and the nature of its political productivity in a specifically martial vein.

Khami Prison was 'notorious as the harshest of the Smith regime's maximum security prisons' ${ }^{63}$ Its maximum security section housed two halls: A and B, the latter made up of single cells, the former of cells of mixed sizes, some large. It contained Dclass prisoners, men considered the most dangerous and who served lengthy sentences. Its population was made up of prisoners considered by both the state and the prisoners themselves to be political, though they had varied backgrounds. In addition to the veterans of Wankie and Sipolilo, who arrived around 1970, and other guerrillas who arrived earlier and later, there were large numbers of untrained men, especially after the mid-1970s, who had been arrested while seeking to cross the border to join the liberation armies or who were convicted of 'recruiting' guerillas. The prison was dominated by ZAPU, but held a minority of ZANU prisoners as well as the ANC men. In the late 1970s, there were probably over 700 prisoners, of whom around 600 were ZAPU. 'Staff' prisoners who worked for the prison authorities were drawn from the ranks of criminal convicts. ${ }^{64}$

The Wankie and Sipolilo veterans described Khami's concentric, looming walls, wide enough to walk on, the overlooking guard towers, and the constantly clanging cell doors, as distressing forms of auditory and physical oppression. ${ }^{65}$ Moffat Hadebe recounted how, when men arrived at Khami, they had to strip naked at the main gate and walk between the first two sets of walls in single file: 'they tell you that your private parts remain here, you go without them.... They tell you that everything 
of yours remains here, you go there just a useless thing. That's Khami. ${ }^{66}$ These men saw themselves as inhabiting enemy territory and they described the rigid routines of prison life as an enemy regime. Life was regulated from the moment of waking until the end of the day in a strict rota of cleaning, ablution, meals, inspections, exercise and labour. ${ }^{67}$ The rota shifted depending on the officer in charge, the Hall one inhabited, and over time. In some periods it was possible to play volleyball and study; at others, days were dominated by a regime of breaking rocks in deep pits. At all times, however, soldiers lived under close scrutiny and with the ever-present threat of violence. Punishments included petty deprivations, violent beatings, pouring cold water in cells at night, 'spare diets' and solitary confinement, the latter - known as the 'dark cell' - was held up as the most awful of fates. ${ }^{68}$ Pilate Dube stressed the impossibility of objection and complaint: 'They would hit you! They would kill you!' ${ }^{69}$ Sly Masuku noted how an incorrect term of address would leave you 'red with blood'.70

The oral accounts of soldiers who lived under this regime have a less purposeful form than those of detained nationalists. The prisoner population was more diverse in its loyalties, while communication and organization was arduous under the best of circumstances, and much harder still if one was relegated to the single cells or solitary confinement. Soldiers' stories outlined a minimalist regime: a command structure intended to defend the identity and capacity of soldiers. They invoked a military view that contrasted with that of their nationalist counterparts. If Gonakudzingwa had its 'State House' and 'government', Khami had a 'High Command', a reference to ZAPU's military hierarchy in exile, and soldiers sought to make it 'a base not a prison'. ${ }^{71}$ In both cases, prisoners sought to echo the 'structures' to which they were loyal outside prison. In Khami, that put the most senior of the military men, the ZAPU commander of the Sipolilo Campaign, Moffat Hadebe, in charge, in alliance with senior ANC men - Freddie Mninzi was identified as the group's political commissar - and men with histories in ZAPU's party and intelligence structures, notably Batandi Mpofu. ${ }^{72}$ These men stressed that they stayed in contact with their superiors outside the prison, including their commanders in Zambia, but that there were long gaps in communication. ${ }^{73}$

Soldiers established secretive committees, and they sought to carry out activities such as education, a perennial focus of all political prisoners. Up to 1972, they were allowed to enroll on external courses, but after that date they were restricted to educating themselves. ${ }^{74}$ They went to great lengths to hold classes, often within cells. Some students even sat 'exams'. This was about job prospects, however, not citizenship. As Ralph Mzamo, who taught classes in English and book-keeping, explained: 'We were preparing for employment in the future. We laid much more stress on that than academic qualifications, because of the realization we were getting old. ${ }^{75}$ There was also education in the sense of political discussion, run by the political commissar Freddie Mninzi. These discussions centred on interpreting news from outside. In this, warders were crucial as a source of newspapers, and much effort was invested in cultivating relations with a small number of friendly (or venal) warders who might carry letters and deliver news. ${ }^{76}$ Mzamo said they had made a special effort to educate the young, untrained men in the prison, and that their political sophistication had impressed even ZAPU president Joshua Nkomo on their release: 'politically they were more sound than the guerrillas', he insisted. ${ }^{77}$

Education in these broad senses played an important role in building and maintaining a common cause, under threat not least from the alternative loyalty of ZANU. Thula Bopela reported an intense debate shortly after his group's arrival over 
whether ZANU prisoners should be considered an enemy force, a view taken by the ZAPU command, who saw ZANU (in Bopela's account) as an ethnic upstart that threatened the revolution. The ANC soldiers debated among themselves, with a minority of four (including Bopela) holding that such action was counterproductive as well as counter to the line of their political leaders. ${ }^{78}$ Some ZAPU soldiers described intermittent tensions, for example over the allocation by guards of new prisoners claimed by ZAPU to the ZANU cells (some guards were said to be politically aligned, for ethnic or other reasons), but also periods of fraternizing and good relations, during which they played volleyball and 'mixed' ${ }^{79}$ Sly Masuku said he and Ralph Mzamo had even sent the ZANU prisoners condolences after the death of their commander Josiah Tongogara. ${ }^{80}$ Many soldiers described as a greater cause of trouble the circulation of rumours of external divisions. The news of ZAPU's split in Zambia in 1970/71 divided loyalties, as it had in Gonakudzingwa. There were also troubles in the wake of offers of early release for statements of allegiance to the ill-fated government of Zimbabwe-Rhodesia. ${ }^{81}$

These challenges to political loyalty rose and fell, alongside other challenges to the maintenance of soldierly discipline. The efforts of Khami's 'High Command' to keep discipline relied in part on an ability to administer corporal punishment in cells, or the more severe punishment of isolation, administered where soldiers displayed disloyalty or engaged in unauthorized transactions with 'staff' prisoners. 'Staff' prisoners worked in the kitchens and so had access to food, and used their privileged position to barter for goods such as tobacco as well as sex, the latter considered categorically incompatible with a soldier's identity. The protection of young, untrained men - such as the growing numbers arrested while trying to cross the border - was of particular concern in this regard. ${ }^{82}$ There were also positive efforts to maintain the health of soldiers' minds and bodies. To keep the body fit, exercises were carried out whenever possible, and eating was enforced. ${ }^{83}$ This latter was not straightforward: soldiers emphasised the terrible quality of the rotten, bug-infested, barely cooked food, and the discipline required to consume it. This was found lacking among, for example, middle class men who had been jailed for 'recruitment'.

Commanders advised them not to look at the food, to talk while eating, and when this was not enough, men were blindfolded and made to eat. In the worst cases, a 'team' was deployed to force men to eat. ${ }^{84}$ Illness also posed a threat to soldiers' bodies. The prison doctor was considered to be part of an enemy structure intent on harm. As a result, soldiers who had medical training such as Actwell Siwela sought to minister to the ill, by befriending guards who could smuggle aspirins and other medicines, and by carrying out medical procedures in the cells, ranging from pulling teeth to applying remedies for piles, a common malady blamed on long periods of sitting on the cold prison floor. ${ }^{85}$ This focus on the body extended to death: commanders tried to prevent the segregation of the mortally ill by prison authorities.

Such practices of bodily care sat side by side with a concern for the soldier's mind. Commanders associated mental illness with prison conditions, which caused malaise and depression, as well as memories of the violence of war and worry over family. All soldiers spoke of the threat of 'madness' ${ }^{86}$ Education and other activities like sport and music played an important role generally, and the commanders instituted a combination of coercion and therapy where mental instability threatened unity and discipline. The ANC political commissar Freddie Mninzi, who had trained in intelligence in the Soviet Union, was deemed to be the best 'counselor' ${ }^{87} \mathrm{He}$ scrutinized cases of persistent rule-breaking or dejection and offered an explanatory narrative that guided the choice of intervention, be it one-on-one discussion, coercion, 
the allocation of a care-taking team, or isolation. ${ }^{88}$ Batandi Mpofu specialized in dealing with soldiers' family worries, and specifically fears over the fidelity of wives, which was considered a pre-eminent threat to mental health and occasioned the most emotional moments in soldiers' story telling decades after the fact. These concerns were shared among detainees in Gonakudzingwa and soldiers in Khami and both had developed an approach which ran counter to the patriarchal traditions of Rhodesia: men were advised that their wives' sexuality was beyond an imprisoned man's control, and the likelihood of infidelity had thus to be accepted. The children of such unions were also to be accepted, and valued as citizens and fighters of the future. As Mpofu explained, 'it was so painful, very painful', but 'you must have an ability of finding a child with different ears from your own, different nose, ... you have to accept it and keep silent.... It's part of the revolution, you see. ${ }^{, 89}$

Soldiers' bodies and minds were thus subjected to a regime of care and discipline in Khami that sought to ensure survival and the retention of a martial identity. These stories were not triumphant: they recounted fighting a war without weapons from deep inside enemy territory, an awful, daily battle that was at best an extended stalemate and at worst a prolonged defeat that left men mad. These accounts were distinct from the tales of bravery and agency of guerrillas at the warfront and nationalist stories of self-government and nation-making in detention, both of which held at least the promise of a better future. The military orders soldiers made in the violent state embrace of Khami was only very problematically heroic. Prison marked an ellipsis in the life stories of these men, who had once trained in foreign lands and fought on the battlefield, that threated their martial identities.

Many of the soldiers of the Wankie and Sipolilo campaign were released from Khami prison only after ZANU's landslide electoral victory in 1980. Regardless of the moment in which their story was told, the ANC soldiers recounted celebrating the outcome as a victory for majority rule. ${ }^{90}$ Their ZAPU comrades were, however, inconsolable at the loss to ZANU, in that moment, and in their telling of it decades later. Thirty years after his release from Khami, Sly Masuku vividly remembered his excitement and expectation of finding a change in 'the faces of the people, that people were independent. But I didn't find anything., 91

\section{Conclusion}

These varied accounts - letters, memoirs and above all oral histories - render visible the many ways in which political prisoners sought to make colonial incarceration productive. Prisoners' modes of self-ordering within the state's embrace produced and were produced by divergent aspirations and imaginaries, failed and realized, celebrated and hidden. They did political work after the fact too, as recidivist memories granted a shifting political valence in the present. In southern Africa, they reveal other realms as well: the making of institutions and ideas in prisons reverberated across liberation struggles, in ways that are little remarked. We have seen in the stories I have recounted that individuals, practices and ideas circulated among war zones, prisons and exile camps. Thus Maurice Nyagumbo wrote to his former fellow prisoners in Mozambique to complain over the accounts he had heard in prison of guerrilla governance in the war zones, while the imprisoned soldiers brought their experience of exile and the camp into Khami's High Command. The most senior nationalists detained in Gonakudzingwa and the soldiers too had had their efforts at self-government disrupted by news of division in exile. Many of the detained nationalists of Gonakudzingwa went on to spend the second half of the 
1970s attempting to stamp their authority on ZAPU's armed wing in Zambia, not least through a contest over jurisprudential ideas and penal regimes. ${ }^{92}$ These spatial and chronological displacements led to intense contestations over legitimate authority that spilled into the post-colonial world. Such stories underline the great complexity involved in tracing the genealogy of ideas and institutions, as well as the importance of developing methodologies for doing so, if we are to understand the legacies of colonial-era incarceration in all its dimensions.

\section{Notes}

${ }^{1}$ Rich bodies of work in this regard have emerged from scholars of Kenya and South Africa.

See contributions by Anderson, Histories of the Hanged; Clough, Mau Mau Memoirs; Elkins, Imperial Reckoning; Buntman, Robben Island; and Gready, Writing as Resistance. Beyond Africa, see particularly the studies of Zinomann, Colonial Bastille, on Vietnam; Arnold, 'The Self and the Cell' on India; and Feldman, Formations of Violence, on Northern Ireland.

${ }^{2}$ Writing about Mau Mau detainees, Peterson, 'The Intellectual Lives', p. 75, makes this point explicitly in response to the work of Elkins, Britain's Gulag, and 'Detention, rehabilitation'.

${ }^{3}$ See Branch, 'Imprisonment and Colonialism in Kenya', pp. 241-2. He rejects the application of the Foucauldian notion of the 'carceral archipelago' to Kenyan institutions in Bernault's influential, A History of Prison, arguing for a violent penal practice aimed at groups not individuals.

${ }^{4}$ Anderson, ‘Guilty Secrets'. See Phillips, ‘The Migrated Archives’, pp.1003-1004, for a skeptical view of the new insights offered by these archives generally.

${ }^{5}$ See Stoler, Along the Archival Grain.

${ }^{6}$ McCracken, 'In the Shadow of Mau Mau', p. 536, fn 2.

${ }^{7}$ McCracken, 'In the Shadow of Mau Mau', p. 547.

${ }^{8}$ There is of course a lengthy debate on the extent to which colonial archives may be used to access the worlds of 'subalterns', notably in the annals of the Subaltern School, but also beyond it. For a discussion relevant to southern Africa history, see Lalu, 'The Grammar of Domination'.

${ }^{9}$ Gready, 'Autobiography and the "Power of Writing”.'

${ }^{10}$ See for example Nuttal, ‘Telling “free” stories?’, Clough, Mau Mau Memoirs, and Schalkwyk, 'Writing from Prison' and 'Chronotypes of the Self.'

${ }^{11}$ See the wide-ranging discussion in Rasch, 'Autobiography after Empire'.

${ }^{12}$ A large literature addresses the qualities of letters. See e.g., Stanley, Documents of Life.

${ }^{13}$ Peterson, 'The intellectual lives', p. 80. 
${ }^{14}$ For a revealing collection of prisoner letters in these regards, see Kathrada, Letters from Robben Island.

${ }^{15}$ See discussions in White, 'Telling More’; Portelli, ‘The Peculiarities'; Summerfield, 'Culture and Composure' and the classic work of Halbwachs, On Collective Memory.

${ }^{16}$ See discussion in Werbner, Memory and the Postcolony, and especially Werbner's introduction 'Beyond Oblivion'.

${ }^{17}$ Steinberg, The Number, pp. 272-278; Filippi, 'Deviance, Punishment and Logics of Subjectification,' pp. 639-42. Filippi draws on letters as well as interviews. She along with others underlines the categorical distinctions drawn by political prisoners between themselves and criminals. Also see Alexander, 'Nationalism and Self-government'; Buntman, Robben Island.

${ }^{18}$ West, 'Voices Twice Silenced.'

${ }^{19}$ Alexander, 'Nationalism and Self-government,' pp. 552-556.

${ }^{20}$ On law specifically in Southern Rhodesia, see Karekwaivanane, The Struggle. The contrast with Kenya is a fascinating one into which I cannot delve in detail here. See Berman and Lonsdale, Unhappy Valley; Anderson, Histories of the Hanged; Branch, 'Imprisonment and Colonialism.'

${ }^{21}$ The state archive, which is fullest in this early moment, contains vast correspondence files that recount negotiations over the most intimate aspects of detainees' lives - family relations, housing, school fees, business and farm management, debts. The records of detainee support groups provide a window on exchanges with officials, which attend to legal and bureaucratic matters, as well as on detainees' lives and views. A record of these interactions can be found in the Terence Ranger Papers (TRP), held in the Weston Library, Oxford University. Also see Ranger's autobiography, Writing Revolt. The National Archives of Zimbabwe (NAZ) contain extensive records of correspondence with detainees and their supporters and among state bureaucracies. See Alexander, 'State Writing.'

${ }^{22}$ Karekwaivanane, The Struggle.

${ }^{23}$ See the account of a key state official involved in these efforts in NAZ, ORAL/256, Francis Anthony Staunton, November 1986.

${ }^{24}$ ZAPU is the Zimbabwe African People's Union and ZANU the Zimbabwe African National Union, which became ZANU(PF) at independence, the PF standing for Patriotic Front.

${ }^{25}$ See Feltoe, ‘Law, Ideology and Coercion’; Munochiveyi, 'Suffering and Protest,' pp. 4952.

${ }^{26}$ See Alexander, 'Political Prisoners’ Memoirs.' 
${ }^{27}$ On India, see the discussion in Arnold, 'The Self and the Cell', p. 30, in which prison writing is cast as a 'nationalist convention'. In recent years, the genre of political memoir in Zimbabwe has become a distinctly critical one in regard to the ruling party's nationalist claims. E.g., see Tekere, Edgar '2Boy’ Zivanai Tekere; Mhanda, Dzino.

${ }^{28}$ On the symbolic politics of heroes and their material and political claims, see discussions in Munochiveyi, Prisoners of Rhodesia, chapter 6; Kriger, Guerrilla Veterans.

${ }^{29}$ On the politics and violence of the 1980s, see CCJP/LRF, Breaking the Silence.

${ }^{30}$ See discussion in Cole, ‘The Uses of Defeat', p. 106.

${ }^{31}$ Munochiveyi, Prisoners of Rhodesia, pp. 13-17, chapter 6.

${ }^{32}$ For a detailed account of life in Gonakudzingwa, see Alexander, 'Nationalism and Selfgovernment.' ZANU members were held at other sites of detention and made similar efforts at self-government. See Munochiveyi, Prisoners of Rhodesia, pp. 121-154.

${ }^{33}$ Interview, R. K. Naik, Oxford, 17 September 2008.

${ }^{34}$ Nkomo, Nkomo, p. 124; Interviews, Naik; John Mzimela, Bulawayo, 4 February 2009.

${ }^{35}$ Interviews, Welshman Mabhena, Bulawayo, 9 October 2008; Fletcher Dulini Ncube, Bulawayo, 1 October 2008; Jane Ngwenya, 14 October 2008; NAZ, MS308/15/1, Detentions and Restrictions 1967, 'Cephas Msipa, or the one that got away’, Free Labour World, November 1976.

${ }^{36}$ There is a rich literature on education in all its senses on Robben Island. Political prisoners in many other locations also considered education a central goal. See Buntman, Robben Island.

${ }^{37}$ Interview, Mabhena.

${ }^{38}$ Interviews, Paul Themba Nyathi, Bulawayo, 29 September 2008; Dulini Ncube; Mabhena; Ngwenya.

${ }^{39}$ There were different kinds of courts in different spaces of nationalist detention, but all established systems of justice and order. Interview, Nyathi; Munochiveyi, Prisoners of Rhodesia.

${ }^{40}$ Nkomo, Nkomo, pp. 133-134; interviews, Mabhena; Dulini Ncube.

${ }^{41}$ Also see Werbner's account of Nkomo’s 1986 speech at the funeral of Lookout Masuku, the former commander of ZAPU's armed wing, who died after a long period of postindependence imprisonment. Werbner, 'Smoke’, pp. 91-92.

${ }^{42}$ See Alexander, McGregor and Ranger, Violence and Memory, chapters 9-11.

${ }^{43}$ On post-2000 politics, see Raftopoulos and Mlambo, Becoming Zimbabwe, and Hammar, Raftopoulos and Jensen, Zimbabwe’s Unfinished Business.

${ }^{44}$ Interviews, Nyathi; Dulini Ncube.

${ }^{45}$ See, e.g., Buntman, Robben Island, on South Africa.

${ }^{46}$ See Munochiveyi, ‘Suffering and Protest', pp. 59-61. 
${ }^{47}$ See Ranger, Writing Revolt, for a vivid account of this period.

${ }^{48}$ Nyagumbo, With the People. Letters cited are held in the Terence Ranger Papers, noted above.

${ }^{49}$ TRP, Maurice, Salisbury Central Prison, to Shelagh, Stockport, UK, 4 August 1978; Maurice, Connemara Prison, to Shelagh Ranger, Pacific Palisades, California, 10 June 1974; Maurice, Que Que Prison, to Terry, 24 August 1974 (smuggled letter).

${ }^{50}$ TRP, Maurice, Salisbury Central Prison, to Shelagh, Stockport, UK, 4 August 1978.

${ }^{51}$ TRP, Maurice, Salisbury Central Prison, to Terry, 18 August 1978; Shelagh, Stockport, UK, to Maurice, 25 September 1978; Maurice, Salisbury Central Prison, to Shelagh, Stockport, UK, 6 October 1978; Shelagh to Maurice, 15 October 1978; Maurice, Salisbury Central Prison, to Shelagh, Stockport, UK, 16 March 1979 and 25 May 1979. ${ }^{52}$ See TRP, Maurice, Salisbury Central Prison, to Shelagh, Stockport, UK; Terry to Maurice, 9 July 1979; Maurice, Salisbury Central Prison, to Shelagh and Terry, Stockport, UK, 17 August 1979; Pers, Comm, Terence Ranger, Oxford, 5 March 2014.

${ }^{53}$ See account in Conradie, 'Preface.'

${ }^{54}$ See Nyagumbo’s letter of 31 August 1979, quoted in Conradie, ‘Epilogue,’ p. 234; TRP, Maurice, Salisbury Central Prison, to Shelagh and Terry, Stockport, UK, 17 August 1979; Maurice, Salisbury Central Prison, to Terry, 12 October 1979; John Conradie to Guy Clutton-Brock, 27 June 1978.

55 TRP, Maurice Nyagumbo, Salisbury Central Prison, to Mr. R. Mugabe and ZANU Central Committee, Maputo, Mozambique, June 1979.

${ }^{56}$ Compare to the letters of Kathrada, Letters, or Suttner, Inside Apartheid's Prisons, in South Africa, for example, or Peterson's Mau Mau study, “The Intellectual Lives.”

${ }^{57}$ See Ralinala, Sithole, Houston and Magubane, 'The Wankie and Sipolilo campaigns' and Macmillan, '“Past History”.' There are also accounts from a Rhodesian view point.

${ }^{58}$ Interviews, Moffat Hadebe (ZAPU, commander of the Sipolilo campaign), Gwanda A1 Resettlement Scheme, 3 February 2009; Sly Masuku (ZAPU), Dromoland, Village 3, 9 August 2010; George Tau (ANC), Rangemore, 8 February 2009; Pilate Dube (ZAPU), Bulawayo, 2 October 2008; Actwell Siwela (ZAPU), Bulawayo, 18 August 2010; Moffat Hadebe and Actwell Siwela, Bulawayo, 28 July 2017. I also draw on interviews with others who played a key role in prisoner organisation in Khami at this time, notably Batandi Mpofu, who served in intelligence in ZAPU, Interview, Bulawayo, 5 February 2009. The two further ANC accounts are Thula Bopela's, in Bopela and Luthuli, Umkhonto we Sizwe, and the transcript of Ralph Mzamo's interview of 21 June 1980, held in the NAZ, Harare, MS591/4.

${ }^{59}$ See Alexander and McGregor, 'War Stories'.

${ }^{60}$ For example, interview, Masuku. 
${ }^{61}$ Bopela and Luthuli, Umkhonto we Sizwe, p. 146.

${ }^{62}$ Interview, Mpofu.

${ }^{63}$ Ling, 'Release from Khami Prison,’ p. 2.

${ }^{64}$ Longstanding prisoner Batandi Mpofu (interview) estimated that, in the late 1970s, there were some 600 ZAPU, 150 ZANU and 15 MK prisoners. In his memoir, Bopela (Bopela and Luthuli, Umkhonto we Sizwe, p. 168) names 15 MK soldiers in around 1970. Ling, a researcher for the International Defence and Aid Fund, 'Release from Khami Prison,' pp. 2-3, reports 673 prisoners in 1977, of whom '95\% were politicals serving sentences ranging from seven years up to life'. Ling visited Khami in March 1980 and found 10 ANC prisoners. Another three were held in Chikurubi Maximum Security prison in Harare.

${ }^{65}$ Interviews, Masuku; Siwela. And see Mzamo’s detailed account of the architecture of Khami, NAZ, MS591/4.

${ }^{66}$ Interview, Hadebe and Siwela.

${ }^{67}$ Accounts of the daily regime are in Mzamo, NAZ, MS591/4, Bopela and Luthuli, Umkhonte we Sizwe, pp. 164-166, and in interview accounts, e.g., interview, Dube.

${ }^{68}$ Interview, Masuku.

${ }^{69}$ Interview, Dube. See also the account in Bopela and Luthuli, Umkhonto we Sizwe, p. 166.

${ }^{70}$ Interview, Masuku.

${ }^{71}$ Interview, Mpofu. Also interviews, Masuku; Hadebe and Siwela.

${ }^{72}$ Interviews, Hadebe, Dube, Tau, Masuku. On Mninzi’s roles, interviews, Siwela, Mpofu.

${ }^{73}$ Interview, Hadebe; Hadebe and Siwela; NAZ, Mzamo, MS591/4.

${ }^{74}$ Bopela and Luthuli, Umkhonto we Sizwe, p. 126. It seems that in the last years of their imprisonment reading materials were allowed once again. Interview, Siwela.

${ }^{75}$ NAZ, Mzamo, MS591/4. Batandi Mpofu and Freddie Mninzi also taught. Interviews, Siwela, Mpofu, Masuku.

${ }^{76}$ E.g., interviews, Siwela; Mpofu. Also see interview with a former Khami prison warder, John Nyamakawo, in Munyaradzi Huni, 'I worked for Smith, I hated the System', Sunday Mail (Harare), 3 July 2016, who held that a small number of guards, himself included, delivered messages and newspapers, among other things, for prisoners.

${ }^{77}$ NAZ, Mzamo, MS591/4. And see Ling, 'Release from Khami’, pp. 5-6. Other soldiers remembered Mzamo organizing lively political debates. Interview, Masuku.

${ }^{78}$ Bopela and Luthuli, Umkhonto we Sizwe, pp. 167-169.

${ }^{79}$ Interviews, Siwela; Dube.

${ }^{80}$ Interview, Masuku.

${ }^{81}$ NAZ, Mzamo, MS591/4; interviews, Hadebe; Masuku; Tau.

${ }^{82}$ Interviews, Mpofu; Dube. 
${ }^{83}$ E.g., interview, Masuku.

${ }^{84}$ Interviews, Siwela; Mpofu.

${ }^{85}$ Interviews, Mpofu; Siwela. Siwela and Pilate Dube had some medical training.

${ }^{86}$ Interviews, Masuku; Hadebe and Siwela.

${ }^{87}$ Interview, Siwela.

${ }^{88}$ Interview, Mpofu.

${ }^{89}$ Interview, Mpofu. Detainees in Gonakudzingwa had established committees to counsel young men with concerns over infidelity, similarly advising them that adultery was to be accepted. Alexander, 'Nationalism and Self-government', p. 562.

${ }^{90}$ This was the case both in Mzamo’s 1980 account, NAZ, MS591/4 and in Bopela's account 25 years later, Bopela and Luthuli, Umkhonto we Sizwe, p. 183. Both men, however, rapidly fell out with the ANC after their release. Ralinala et al., 'The Wankie and Sipolilo Campaigns', p. 528.

${ }^{91}$ Interview, Masuku.

${ }^{92}$ Alexander, 'Loyalty and Liberation.'

\section{References}

Alexander, Jocelyn. "Nationalism and Self-government in Rhodesian Detention: Gonakudzingwa, 1964-1974.” Journal of Southern African Studies 37, no. 3 (2011): 551-570.

Alexander, Jocelyn. "Loyalty and Liberation: The Political Life of Zephaniah Moyo.” Journal of Eastern African Studies 11, no. 1 (2017): 166-187.

Alexander, Jocelyn. “Political Prisoners' Memoirs in Zimbabwe: Narratives of Self and Nation.” Cultural and Social History 5, no. 4 (2008): 395-409.

Alexander, Jocelyn. “State Writing, Subversion and Citizenship in Southern Rhodesia's state of emergency, 1959-1960.” Canadian Journal of African Studies, forthcoming.

Alexander, Jocelyn and JoAnn McGregor. “War Stories: Guerrilla Narratives of Zimbabwe’s Liberation War.” History Workshop Journal 57, no. 1 (2004): 79-100.

Anderson, David. Histories of the Hanged: Britain's Dirty War in Kenya and the End of the Empire. London: Weidenfeld and Nicolson, 2005.

Anderson, David. “British abuse and torture in Kenya’s counter-insurgency, 1952-1960.” Small Wars and Insurgencies 23, nos. 4-5 (2012): 700-719.

Anderson, David. “Guilty Secrets: Deceit, Denial and the Discovery of Kenya’s 'Migrated Archive'.” History Workshop Journal 80, no. 1 (2015): 142-160. 
Arnold, David. “The Self and the Cell: Indian Prison Narratives as Life Histories.” In Telling Lives in India: Biography, Autobiography, and Life History, edited by David Arnold and Stuart Blackburn. Bloomington: Indiana University Press, 2004.

Berman, Bruce and John Lonsdale. Unhappy Valley: Conflict in Kenya and Africa. London: James Currey, 1992.

Bernault, Florence. A History of the Prison and Confinement in Africa. Portsmouth, NH: Heinemann, 2003.

Bopela, Thula and Daluxolo Luthuli. Umkhonto we Sizwe: Fighting for a Divided People. Alberton, South Africa: Galago Books, 2005.

Branch, Dan. "Imprisonment and Colonialism in Kenya, c. 1930-1952: Escaping the Carceral Archipelago.” International Journal of African Historical Studies 38, no. 2 (2005): 239265.

Buntman, Fran Lisa. Robben Island and Prisoner Resistance to Apartheid. Cambridge: Cambridge University Press, 2003.

Catholic Commission for Justice and Peace/Legal Resources Foundation, Breaking the Silence, Building True Peace: A Report on the Disturbances in Matabeleland and the Midlands, 1980 to 1988. Harare: CCJP/LRF, 1997.

Clough, Marshall. Mau Mau Memoirs: History, Memory and Politics. Boulder: Lynne Rienner, 1998.

Cole, Jennifer. “The Uses of Defeat: Memory and Political Morality in East Madagascar.” In Memory and the Postcolony: African anthropology and the critique of power, edited by Richard Werbner. London: Zed Books, 1998.

Conradie, John. "Preface” and “Epilogue”. In Maurice Nyagumbo, With the People: An autobiography from the Zimbabwe struggle. London: Allison and Busby, 1980.

Elkins, Caroline. "Detention, Rehabilitation, and the Destruction of Kikuyu Society.” In Mau Mau and Nationhood: Arms, Authority, Narration, edited by E. S. Atieno Odhiambo and John Lonsdale. Oxford: James Currey, 2004.

Elkins, Caroline. Britain’s Gulag: The Brutal End of Empire in Kenya. London: Jonathan Cape, 2005.

Feldman, Allen. Formations of Violence: The Narrative of the Body and Political Terror in Northern Ireland. Chicago: University of Chicago Press, 1991.

Feltoe, G. "Law, Ideology and Coercion in Southern Rhodesia.” MPhil Thesis, University of Kent, 1978.

Filippi, Natacha. "Deviance, Punishment and Logics of Subjectification during Apartheid: Insane, Political and Common-Law prisoners in a South African Gaol.” Journal of Southern African Studies 37, no. 3 (2011): 627-644. 
Gready, Paul. Writing as resistance: Life stories of imprisonment, exile, and homecoming from apartheid South Africa. Lanham: Lexington Books, 2003.

Gready, Paul. “Autobiography and the 'Power of Writing': Political Prison Writing in the Apartheid Era”. Journal of Southern African Studies 19, no. 3 (1993): 489-523.

Halbwachs, Maurice. On Collective Memory. Chicago: University of Chicago Press, 1992.

Hammar, Amanda, Brian Raftopoulos and Stig Jensen, eds. Zimbabwe's Unfinished Business: Rethinking Land, State and Nation in the Context of Crisis. Harare: Weaver Press, 2003. Karekwaivanane, George. The Struggle over State Power in Zimbabwe: Law and Politics since 1950. Cambridge: Cambridge University Press, 2017).

Kathrada, Ahmed. Letters from Robben Island: A Selection of Ahmed Kathrada's Prison Correspondence, 1964-1989, edited by Robert D. Vassen. East Lansing, Michigan: Michigan State University Press, 1999.

Kriger, Norma. Guerrilla Veterans in Post-War Zimbabwe: Symbolic and Violent Politics 1980-1987. Cambridge: Cambridge University Press, 2003.

Lalu, Premesh. "The Grammar of Domination and the Subjection of Agency: Colonial Texts and Modes of Agency.” History and Theory 39, no. 4 (2000): 45-68.

Ling, Margaret. "Release from Khami Prison - the MK fighters in Ian Smith’s Rhodesia.” Ms., March 2009.

Macmillan, Hugh. “'Past History Has Not Been Forgotten’: The ANC/ZAPU Alliance - the Second Phase, 1978-1980.” Journal of Southern African Studies 43, no. 1 (2017): 179194.

McCracken, John. "In the Shadow of Mau Mau: Detainees and Detention Camps during Nyasaland's State of Emergency.” Journal of Southern African Studies 27, no. 3 (2011): 535-550.

Mhanda, Wilfred. Dzino: Memories of a Freedom Fighter. Harare: Weaver Press, 2011.

Munochiveyi, Munyaradzi. Prisoners of Rhodesia: Inmates and Detainees in the Struggle for Zimbabwean Liberation, 1960-1980. New York: Palgrave Macmillan, 2014.

Munochiveyi, Munyaradzi. "Suffering and Protest in Rhodesian Prisons during the Zimbabwean Liberation Struggle.” Journal of Southern African Studies 41, no. 1 (2015): 47-61.

Nuttal, Sarah. "Telling 'free’ stories? Memory and democracy in South African autobiography since 1994.” In Negotiating the Past: The Making of Memory in South Africa, edited by Sarah Nuttall and Carli Coetzee. Cape Town: Oxford University Press, 1998.

Nkomo, Joshua. Nkomo: The Story of my Life. London: Methuen, 1984.

Nyagumbo, Maurice. With the People: An autobiography from the Zimbabwe struggle. London: Allison and Busby, 1980. 
Peterson, Derek. “The Intellectual Lives of Mau Mau Detainees.” Journal of African History 49, no. 1 (2008): 73-91.

Phillips, David. "The Migrated Archives and a Forgotten Corner of Empire: The British Borneo Territories.” Journal of Imperial and Commonwealth History 44, no. 6 (2017): 1001-1019.

Portelli, Alessandro. “The Peculiarities of Oral History.” History Workshop Journal 12, no. 1 (1981): 96-107.

Raftopoulos, Brian and Alois Mlambo, eds. Becoming Zimbabwe: A History form the Precolonial period to 2008. Harare: Weaver Press, 2009.

Ralinala, Rendani Moses, Jabulani Sithole, Gregory Houston, and Bernard Magubane, “The Wankie and Sipolilo campaigns”. In The Road to Democracy in South Africa, Vol. 1 (1960-1970), South African Democracy Education Trust. Cape Town: Zebra Press, 2004.

Rasch, Astrid. “Autobiography after Empire: Individual and collective memory in dialogue.” PhD Thesis, University of Copenhagen, 2016.

Schalkwyk, David. “Writing from prison.” In Senses of Culture: South African Culture Studies, edited by Sarah Nuttall and Cheryl-Ann Michael, 279-97. Oxford: Oxford University Press, 2000.

Schalkwyk, David. "Chronotypes of the Self in the Writings of Women Political Prisoners in South Africa.” In Apartheid Narratives, edited by Nahem Yousaf. Amsterdam: Rodopi, 2001.

Stanley, C., ed. Documents of life Revisited: Narrative and Biographical Methodology for a $21^{\text {st }}$ Century Critical Humanism. Burlington: Ashgate, 2013.

Steinberg, Jonny. The Number: One man's search for identity in the Cape underworld and prison gangs. Cape Town: Jonathan Ball, 2004.

Stoler, Ann Laura. Along the Archival Grain: Epistemic Anxieties and Colonial Common Sense. Princeton: Princeton University Press, 2009.

Summerfield, Penny. "Culture and Composure: Creating Narratives of the Gendered Self in Oral History Interviews.” Cultural and Social History 1, no. 1 (2004): 65-93.

Suttner, Raymond. Inside Apartheid's Prison: Notes and Letters of Struggle. Pietermaritzburg: University of Natal Press, 2001.

Tekere, Edgar. Edgar “2Boy” Zivanai Tekere: A Lifetime of Struggle. Harare: Sapes Books, 2007.

Werbner, Richard, ed. Memory and the Postcolony: African anthropology and the critique of power. London: Zed Books, 1998. 
Werbner, Richard. “Beyond Oblivion: Confronting Memory Crisis.” In Memory and the Postcolony: African anthropology and the critique of power, edited by Richard Werbner. London: Zed Books, 1998.

Werbner, Richard. "Smoke from the Barrel of a Gun: Postwars of the Dead, Memory and Reinscription in Zimbabwe.” In Memory and the Postcolony: African anthropology and the critique of power, edited by Richard Werbner. London: Zed Books, 1998.

West, Harry. "Voices Twice Silenced.” Anthropological Theory 3, no. 3 (2003): 343-365.

White, Luise. "Telling More: Lies, Secrets and History.” History and Theory 39, no. 4 (2000): 11-22.

Zinomann, Peter. The Colonial Bastille: A History of Imprisonment in Vietnam, 1862-1940. Berkeley: University of California Press, 2001. 